\title{
Weed Suppression by Cover Plants in the Amazonian
}

\author{
Leandro Amorim Damasceno ${ }^{1}$, José Eduardo Borges Carvalho ${ }^{2}$, Francisco Alisson Xavier ${ }^{2}$, \\ Ansselmo Ferreira dos Santos ${ }^{3}$, Gerlândio Suassuna Gonçalves ${ }^{4}$, Alan Ferreira Leite de Lima ${ }^{5}$, \\ Wildson Benedito Mendes Brito ${ }^{5}$, Cláudio Luiz Leone Azevedo ${ }^{2} \&$ José Ferreira da Silva $^{5}$ \\ ${ }^{1}$ Federal Instituto of Amazonas, Eurinepé, AM, Brazil \\ ${ }^{2}$ Embrapa Fruticultura e Mandioca, Cruz das Almas, BA, Brazil \\ ${ }^{3}$ Federal Instituto of Mato Grosso, Juína, MT, Brazil \\ ${ }^{4}$ Federal University of Amazonas, Itacoatiara, AM, Brazil \\ ${ }^{5}$ Federal University of Amazonas, Manaus, AM, Brazil \\ Correspondence: José Ferreira da Silva, Avenida Rodrigo Octavio J. Ramos, 7200, Campus UFAM, Setor Sul, \\ CEP: 69080-900, Manaus, Amazonas, Brazil. Tel: 55-929-9981-9690. E-mail: jfsilva@ufam.edu.br
}

Received: November 11, $2018 \quad$ Accepted: April 10, $2019 \quad$ Online Published: May 31, 2019

doi:10.5539/jas.v11n7p148

URL: https://doi.org/10.5539/jas.v11n7p148

\begin{abstract}
Abstrac
The productivity of citrus plants has not reached its maximum potential due to the action of several factors that directly affect agricultural profitability. Among these factors, weed interference has a great importance since it causes a reduction in crop productivity. The aim of this study was to assess the effect of different cover crops on suppression of weeds in an orange orchard. The research was conducted in a commercial orange production area located in Rio Preto da Eva, AM, Brazil. The experimental design was a randomized block design with six treatments and four replications. Treatments were control, millet, jack bean, forage turnip, brachiaria, millet + jack bean. The evaluated characteristics were weed density, soil cover percentage, total weed dry matter, total cover plant dry matter and growth indices (leaf area index, leaf area ratio, and specific leaf area). Cover plants provided a good dry matter production and had a suppressive effect on weed growth, except for forage turnip. Brachiaria and jack bean presented the highest values of leaf area index and leaf area ratio.
\end{abstract}

Keywords: brachiaria, Citrus sinensis (L.) Osbeck, jack bean, millet, forage turnip

\section{Introduction}

Brazil became the largest orange producer in 2017 ahead of the United States, in second place, and China, in third place. The production of this crop in December 2017 reached 18.7 million tons, produced in 629.8 thousand hectares (IBGE (Instituto Brasileiro de Geografia e Estatística), 2017). The main producing states are São Paulo and Minas Gerais.

However, among the Brazilian states with the greatest potential for citrus cultivation is the Amazonas, with a harvested area of 3,265 hectares and an average yield of 71,830 tons of orange (IBGE, 2017). This activity is favored by compensating prices of citrus fruits and suitable climate conditions for over the year. However, most of the production comes from small orchards, with little use of cultivation technologies, which contributes to a low average productivity.

Technological limitations and inadequate management of orchards are threats to the sustainability of the crop. Currently, the conventional system of citrus production in the Amazonas adopts practices that imply a high production cost and environmental risk (Coelho \& Nascimento, 2004), mainly in tropical and subtropical conditions, in which the use of harrowing and herbicides applied in pre-emergence are frequent, resulting in soil exposure to the direct action of rain and wind. Compaction and erosion have motivated some field studies to assess weed management alternatives in the crop interrow, such as the use of cover plants to minimize losses, exploiting more rationally the natural resources (Carvalho, Paes, \& Menegucci, 2001; Carvalho, Montebeller, Franco, Valcarcel, \& Bertol, 2005).

Weeds compete with crops mainly for nutrients, water, and light. In addition, they host potential pests and diseases, interfere with soil tillage, irrigation, and harvesting operations, raising production costs (Lineares, Boote, Chase, Ferguson, \& McSorley, 2008). Therefore, many producers use different weed management methods, including 
crop rotation, conventional tillage at sowing, and the use of competitive cultivars (Welch, Behnke, Davis, Masiunas, \& Villamil, 2016).

However, many of these methods require a long time in the field, heavy machinery traffic, and intensive soil tillage, which can lead to soil compaction, erosion, and changes in soil nutrient and water dynamics (Welch et al., 2016). Thus, studies that aim at efficient weed control methods in a way that integrates ecological and economic concepts and that involve a rationalization of resources are needed.

One of these methods that have been shown to be effective is weed suppression by the use of cover plants. Sturm, Peteinatos, and Gerhards (2018) clarify that the ability of cover plants to suppress weeds is characterized by the competition for light, water, space, and nutrients. Their correct use provides ecological and economic benefits in the field, including nutrient recycling and soil erosion reduction.

The effects of the practice of using cover plants on crop productivity are numerous due to the improvement of soil physical, chemical, and biological conditions, reduction of pest and pathogen incidence, biological fixation of atmospheric nitrogen, and reduction of weed population (Castro \& Lombardi Neto, 1992; Gelmini, Trani, Sales, \& Victoria Filho, 1994; Gravena et al., 1998).

Recently, many studies have demonstrated the benefits of weed suppression, such as suppression in an effective and sustainable way and with a reduced use of herbicides (Uchino et al., 2012; Dorn \& Van Der Heijden, 2015). In addition, it assists in increasing integrated weed management strategies and brings economic benefits to the producer (Eshel et al., 2015; Gfeller, Herrera, Tschuy, \& Mirth, 2018).

Although the benefits of using cover plants depend on soil and climate conditions, in Brazil, a large part of the researches that deal with studies with cover plants is restricted to the South and Southeast regions, where climate conditions are very different from those found in the northern region. In addition, when considering only citrus cultivation itself, only one single research carried out by Lineares et al. (2008) with organic citrus grown in Florida, USA, could be found in the literature. These authors observed that cover plants such as radish, winter rye, and crimson clover provide and excellent weed suppression, with a more efficient control than other methods, including the conventional cultivation.

Therefore, studies that investigate the ability and adaptability of different cover plants on weed suppression aiming at its control in areas with citrus orchards in northern Brazil are needed, mainly in the Amazonas State, which has a small-scale cultivation and little investment in technological infrastructure. Considering that, this study aimed to assess the effect of different soil cover plants on weed suppression in an area cultivated with orange in Rio Preto da Eva, AM, Brazil.

\section{Material and Methods}

The experiment was carried out in a citrus commercial orchard located in Rio Preto da Eva, AM, Brazil, at the geographical coordinates $02^{\circ} 42^{\prime} 24.1^{\prime \prime} \mathrm{S}$ and $59^{\circ} 26^{\prime} 02.6^{\prime \prime} \mathrm{W}$ (Figure 1). The experiment was performed in an orchard of Pera orange (Citrus sinensis (L.) Osbeck) grafted on Rangpur lime (Citrus limonia (L.) Osbeck) with four years of age and planted at a spacing of $7.0 \times 4.0 \mathrm{~m}$. 


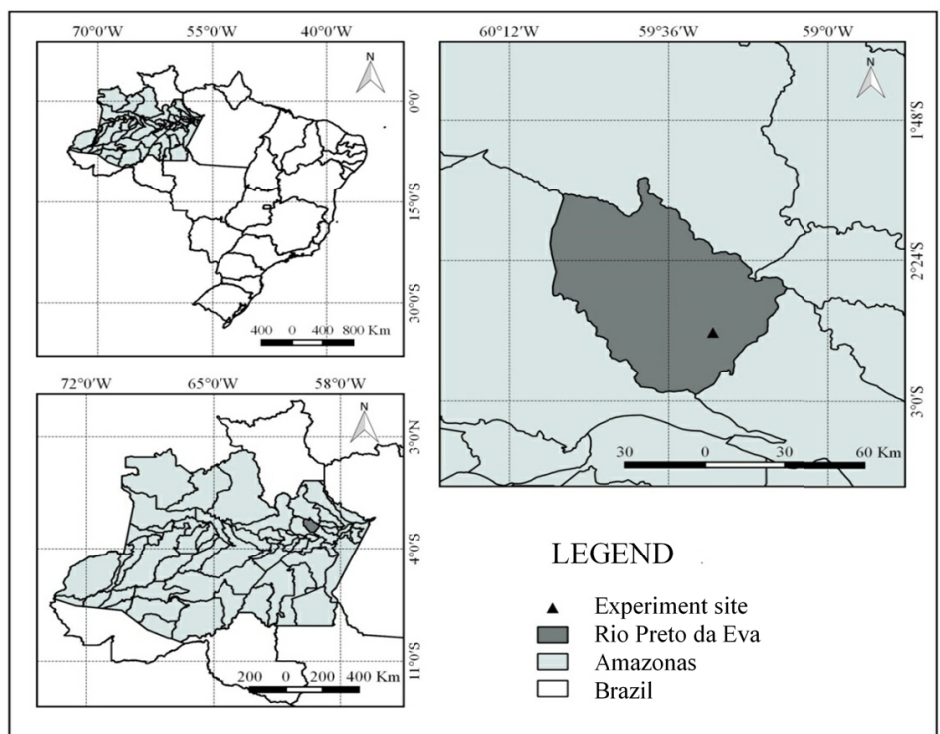

Figure 1. Climatological water balance of the study region during the experimental period. Source: Inmet network data. Manaus, AM, Brazil, 2016

According to the Köppen classification, the regional climate is classified as Af, i.e. a warm and humid climate with an average annual temperature of $27^{\circ} \mathrm{C}$, average annual precipitation of $2,200 \mathrm{~mm}$, and relative air humidity of around 88\% (Alvares, Stape, Sentelhas, Gonçalves, \& Sparovek, 2013). The monthly distribution of precipitation and water balance of the region during the experimental period are shown in Figure 2.

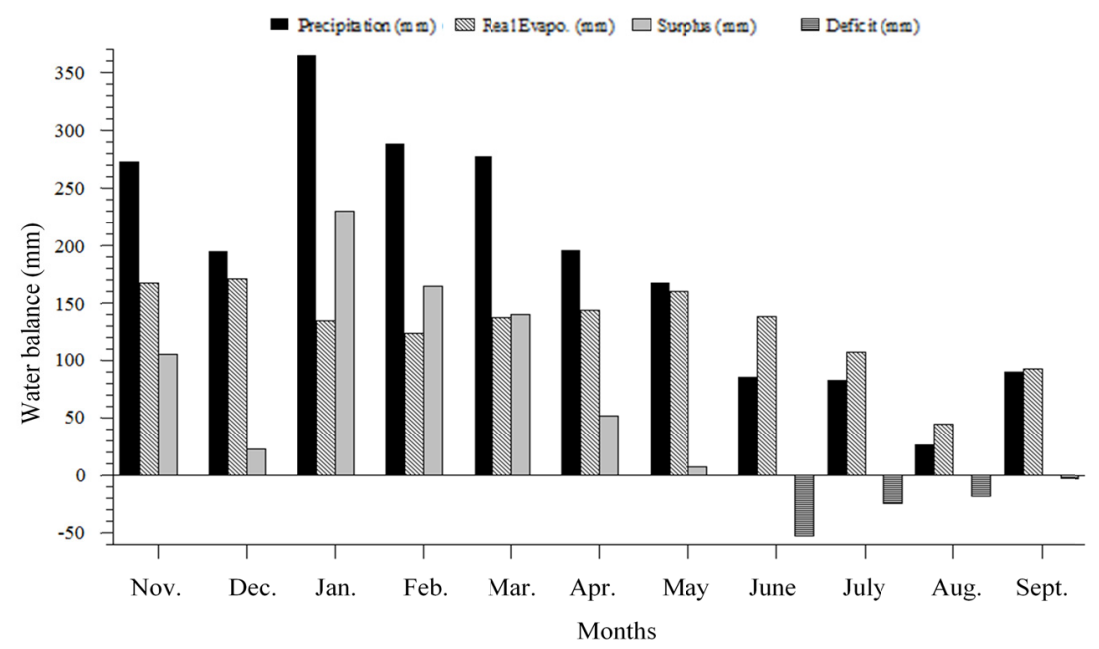

Figure 2. Climatological water balance of the study region during the experimental period. Source: Inmet network data. Manaus, AM, Brazil, 2016

The soil of the orchard was classified as clayey Ultisol (Argissolo Amarelo distrófico, Brazilian Soil Classification System) (Embrapa (Empresa Brasileira De Pesquisa Agropecuária), 2013). The chemical characteristics in the 0 to $20 \mathrm{~cm}$ layer in the planting interrow are shown in Table 1. 
Table 1. Soil chemical characterization of the orchard in Rio Preto da Eva, AM, Brazil, 2012

\begin{tabular}{|c|c|c|c|c|c|c|c|c|c|c|c|c|}
\hline $\mathrm{pH}$ & ${ }^{1} \mathrm{H}+\mathrm{Al}$ & $\mathrm{Al}$ & $\mathrm{K}^{+}$ & $\mathrm{Ca}$ & $\mathrm{Mg}$ & ${ }^{2} \mathrm{SB}$ & $3 \mathrm{t}$ & ${ }^{4} \mathrm{~T}$ & ${ }^{5} \mathrm{~V}$ & ${ }^{6} \mathrm{~m}$ & $\mathrm{P}$ & ${ }^{7} \mathrm{OM}$ \\
\hline $\mathrm{H}_{2} \mathrm{O}$ & --------- & ---- & ------ & $-\mathrm{cmc}$ & $\mathrm{kg}^{-1}-$ & ------ & 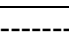 & ------- & --------- & -------- & $\mathrm{mg} \mathrm{kg}^{-1}$ & $\mathrm{~g} \mathrm{~kg}^{-1}$ \\
\hline 4.20 & 5.77 & 0.90 & 0.04 & 0.73 & 0.45 & 1.22 & 2.12 & 6.99 & 17.45 & 42.45 & 3.00 & 29.30 \\
\hline
\end{tabular}

Note. ${ }^{1}$ Potential acidity; ${ }^{2}$ sum of bases; ${ }^{3}$ effective cation exchange capacity; ${ }^{4}$ potential cation exchange capacity; ${ }^{5}$ base saturation; ${ }^{6}$ aluminum saturation; ${ }^{7}$ soil organic matter.

The experimental design was a randomized block design with six treatments and four replications. The treatments with cover plants were control (spontaneous vegetation), millet (Pennisetum glaucum (L.) Leeke), jack bean (Canavalia ensiformis L.), forage turnip (Raphanus sativus L.), brachiaria (Urochloa decumbens Stapf), and millet + jack bean in a ratio of 1:1. The experimental units were composed of $128 \mathrm{~m}^{2}$ ( 2 rows $16 \mathrm{~m}$ long and $4 \mathrm{~m}$ wide).

Before sowing the species, the herbicide Paraquat $\left(400 \mathrm{~g} \mathrm{ha}^{-1}\right)$ was applied in the orchard interrow with a boom sprayer. Subsequently, liming was carried out by applying $3.6 \mathrm{t} \mathrm{ha}^{-1}$ of dolomitic limestone with a $91 \%$ relative power of total neutralization and incorporating it with a harrow. Only the application of herbicide and liming was carried out in the control treatment.

Cover plant seeds were randomly distributed to the experimental unit at the beginning of the rainy season (January/2012) at the following densities: $120 \mathrm{~kg} \mathrm{ha}^{-1}$ of jack bean, $20 \mathrm{~kg} \mathrm{ha}^{-1}$ of forage turnip, $20 \mathrm{~kg} \mathrm{ha}^{-1}$ of millet, and $16 \mathrm{~kg} \mathrm{ha}^{-1}$ of brachiaria. For the treatment with millet + jack bean, $10+60 \mathrm{~kg} \mathrm{ha}^{-1}$ of seeds were used. Each cover plant species was mixed with $4.16 \mathrm{~kg}$ of single superphosphate, being broadcast applied in the citrus interrow, followed by incorporation to the soil with a rake. In the control treatment, a mowing was carried out at the same time as the sowing of the cover plants in order to provide the same condition for all treatments.

For plant sampling, a sampler of $1 \mathrm{~m}^{2}$ was randomly placed 2 times in the useful area of each plot at 90 days after sowing (DAS), the period in which all the cover plants were at the point considered adequate to be cut. The plant shoot inside the sampler was cut close to the soil, counted, identified, and taken to the laboratory. This procedure was also performed for the control treatment. After measuring the leaf area of the cover plants with a LI-COR $3050 \mathrm{~A}$ area meter equipment, the plants were dried in a forced air circulation oven at $75^{\circ} \mathrm{C}$ until constant weight. Density was determined in this same sampling, and dry matter of the weeds present in the treatments was determined using the cover plants.

The leaf area ratio (LAR), specific leaf area (SLA), and leaf area index (LAI) were calculated according to the data of leaf area and dry matter, as in Cairo, Oliveira, and Mesquita (2008).

The degradation rate of cover plants in the field was quantified by the litterbag method by using polyethylene bags. The bags had a $5-\mathrm{mm}$ mesh, which allowed the colonization by microorganisms and invertebrates in the cover material. An amount of $20 \mathrm{~g}$ of dry matter of cover plants was placed in each litterbag. These bags were then randomly distributed in each experimental unit on the ground of the interrow of the citrus orchard. The periods in which the litterbags remained in the field were $7,14,28,56,84,112$, and 140 days. At the end of each period, a litterbag was taken per plot and the residual cover material was dried in a forced air circulation oven at $75^{\circ} \mathrm{C}$ until constant weight and then weighed.

The difference between the initial dry weight $(20 \mathrm{~g})$ and that obtained at the end of each period was used to quantify the loss of dry matter by decomposition over the assessed period. The decomposition rate of plant residues was estimated by the exponential mathematical model described by Thomas and Asakawa (1993), according to Equation 1:

$$
X=X_{0} \cdot \mathrm{e}^{-k t}
$$

where, $X$ is the remaining amount of dry matter after the period of time $t$ (days), $X_{0}$ is the initial amount of dry matter, and $k$ is the decomposition constant of the residue.

To determine the decomposition constant $(k)$ of each treatment, the following neperian logarithm (In) was applied (Equation 2):

$$
k=\ln \left(X / X_{0}\right) / t
$$

The half-life time $\left(\mathrm{T}^{1 / 2}\right)$ of the remaining residues was calculated from the $k$ value by using the expression proposed by Paul and Clark (1996), which expresses the time required for $50 \%$ decomposition to occur, as described in Equation 3:

$$
T^{1 / 2}=0.693 / k
$$


To quantify the effect of cover plants on the suppression of weed growth, the relative neighbor effect (RNE) was calculated according to Smith, Atwood, Pollnac, and Warren (2015) (Equation 4):

$$
R N E=\left(P_{\text {control }}-P_{\text {mixture }}\right) / X
$$

where, $P_{\text {control }}$ is the weed biomass in the control treatment, $P_{\text {mixture }}$ is the weed biomass in the presence of a cover plant, and $X$ is the $P_{\text {control }}$ if $P_{\text {control }}>P_{\text {mixture }}$ or the $P_{\text {mixture }}$ if $P_{\text {mixture }}>P_{\text {control }}$.

Thus, values of RNE $=1$ indicate a complete weed suppression by cover plants, RNE $=0$ indicate a complete weed suppression by cover plants, and RNE $=-1$ indicate the facilitation of the weed by the cover plant.

The results were submitted to analysis of variance and the means of the treatments were compared by the Tukey's test $(\mathrm{p} \leq 0.05)$ using the software Assistat (Silva, 2012).

\section{Results and Discussion}

All the assessed variables of the cover plants were significant (Table 2). The treatments with brachiaria, millet, and jack bean + millet did not differ from each other as they presented a higher stem weight, followed by jack bean and forage turnip.

Regarding leaf dry matter, jack bean presented a higher weight in relation to the other cover plants, with a value of $2.44 \mathrm{tha}^{-1}$. The leaf dry matter of treatments with brachiaria, millet and jack bean + millet did not differ from each other at a $5 \%$ probability. The forage turnip presented the lowest weight of leaf dry matter. This result is similar to that found by Reis, Azevedo, Albuquerque, and Junior (2013), who also observed a low leaf dry matter production for forage turnip, when compared to the other species. This may be related to its growth cycle, which was early in this research and reached $50 \%$ flowering at 38 days after sowing and presented total senescence of leaves at 90 days.

The total dry matter production for brachiaria was $6.35 \mathrm{tha}^{-1}$ at 90 days $\left(70.55 \mathrm{~kg} \mathrm{day}^{-1} \mathrm{ha}^{-1}\right)$ after sowing, and did not differ from the other treatments, except for forage turnip. This value is lower than that obtained by Montanari, Carvalho, Teixeira Filho, and Dalchiavon (2013), who observed a value of $23.6 \mathrm{tha}^{-1}$ at 107 days $\left(220.56 \mathrm{~kg} \mathrm{day}^{-1}\right.$ $\mathrm{ha}^{-1}$ ). The forage turnip presented the lowest total dry matter weight, with a value of $1.08 \mathrm{tha}^{-1}$. This difference in growth per day may be due to the length of day, which was lower than the critical photoperiod, reducing the period of dry matter accumulation of forage turnip and brachiaria.

Faversani, Cassol, Piva, Minato, and Rocha (2014) assessed the soil cover rate of winter plants at 15, 30, 45, 60, 75, and 90 days after emergence in 2011 and 2012, in Pato Branco, PR, Brazil. The cover plants presented different performances. Forage turnip was the species that covered the soil faster, being superior in all the assessed dates, followed by vetch (Vicia villosa Roth), black oat (Avena strigosa Schreber), and forage pea (Pisum sativum L.). These results were due to the light exposure above the critical photoperiod, unlike the response found in our experiment.

Halde, Gulden, and Entz (2014) conducted an experiment at the Morrison Research Station in Carman, Manitoba, in the Northern Great Plains of Canada, with six plant species: vetch (Vicia villosa Roth), forage pea (Pisum sativum L.), forage turnip (Raphanus sativus L.), sunflower (Helianthus annuus L.), flax (Linum usitatissimum L.), and barley (Hordeum vulgare L.). The authors found that the remaining biomass of the forage turnip presented the lowest value among all the plant species. The treatments jack bean, millet, and the mixture presented values of dry matter production of $5,6.11$, and $5.18 \mathrm{tha}^{-1}$, respectively. 
Table 2. Average values of stem dry matter weight (SDMW), leaf dry matter weight (LDMW), total dry matter weight (TDMW), leaf area (LA), specific leaf area (SLA), leaf area ratio (LAR), and leaf area index (LAI) of soil cover species. Rio Preto da Eva, AM, Brazil, $2012^{(1)}$

\begin{tabular}{|c|c|c|c|c|c|c|c|}
\hline Treatment & SDMW & LDMW & TDMW & LA & SLA & LAR & LAI \\
\hline & \multicolumn{3}{|c|}{----------------- t ha' } & $\mathrm{m}^{2}$ & \multicolumn{3}{|c|}{----- $\mathrm{m}^{2} \mathrm{~kg}^{-1} \mathrm{DM}$------ } \\
\hline Brachiaria & $4.80 \mathrm{a}$ & $1.50 \mathrm{~b}$ & $6.35 \mathrm{a}$ & $2.38 \mathrm{ab}$ & $15.70 \mathrm{a}$ & $3.78 \mathrm{ab}$ & $2.38 \mathrm{ab}$ \\
\hline Forage turnip & $1.08 \mathrm{c}$ & $0.00 \mathrm{c}$ & $1.08 \mathrm{~b}$ & $0.00 \mathrm{~d}$ & $00.00 \mathrm{~b}$ & $0.00 \mathrm{~d}$ & $0.00 \mathrm{~d}$ \\
\hline Jack bean & $2.55 \mathrm{bc}$ & $2.44 \mathrm{a}$ & $5.00 \mathrm{a}$ & $2.79 \mathrm{a}$ & $11.52 \mathrm{a}$ & $5.60 \mathrm{a}$ & $2.79 \mathrm{a}$ \\
\hline Millet & $5.08 \mathrm{a}$ & $1.02 \mathrm{~b}$ & $6.11 \mathrm{a}$ & $1.12 \mathrm{~cd}$ & $11.11 \mathrm{a}$ & $1.87 \mathrm{c}$ & $1.12 \mathrm{~cd}$ \\
\hline Jack bean + millet & $4.21 \mathrm{ab}$ & $0.97 \mathrm{~b}$ & $5.18 \mathrm{a}$ & $1.50 \mathrm{bc}$ & $15.86 a$ & $2.89 b c$ & $1.51 \mathrm{bc}$ \\
\hline Mean & 3.55 & $1.18^{-1}$ & 4.75 & 1.56 & $10.86^{-1}$ & 2.83 & 1.56 \\
\hline LSD & 2.08 & 0.84 & 2.13 & 1.12 & 5.87 & 1.84 & 1.12 \\
\hline $\mathrm{CV}(\%)$ & 25.99 & 31.66 & 19.89 & 32.06 & 23.98 & 28.83 & 32.06 \\
\hline
\end{tabular}

Note. ${ }^{(1)}$ Means followed by the same letter in the columns do not differ from each other by the Tukey's test at $1 \%$ probability $(p \leq 0.01)$.

Biomass production means an irreversible increase in the mass of leaves, stems, fruits, and roots over time. These attributes are quantitative and can be used to compare and use of different soil cover (Reis et al., 2013).

The leaf area of cover plants presented significant differences (Table 2). The treatments jack bean and brachiaria presented the highest values of leaf area at 90 days after sowing, while forage turnip, which was under leaf senescence at that time, showed lower values for the growth variables.

The specific leaf area represents the accumulation of reserves of cover plants (Cairo et al., 2008). No difference was observed between the specific leaf area of cover species, except for the forage turnip, which was completely defoliated at the assessment time.

For the leaf area ratio, the treatments jack bean, brachiaria and the mixture jack bean + millet present superiority in relation to millet and forage turnip. The analysis of the leaf area ratio allows detecting the translocation and partition of assimilates to leaves in relation to the dry matter of the aerial part of the plant (Cairo et al., 2008). According to Soares, Negreiros, Lopes, Dombroski, and Lucena (2013), the leaf area ratio decreases with plant ontogenesis. We can infer that the value of the leaf area ratio shows that the millet accumulates its reserves in the roots and the stem.

The treatment jack bean showed the highest leaf area index $\left(2.79 \mathrm{~m}^{2} \mathrm{~m}^{-2}\right)$, followed by brachiaria, jack bean + millet, and millet, with values of $2.38,1.51$, and $1.12 \mathrm{~m}^{2} \mathrm{~m}^{-2}$, respectively. The leaf area index represents the total leaf area per unit area of the land, and it serves as an indicator of the surface available for interception and light absorption. This index is very variable across plant species and across sampling times. In this evaluation, the bean-pig treatment showed a high capacity of covering the area of soil available to this vegetable.

Weed density found in the treatments is shown in Figure 3.

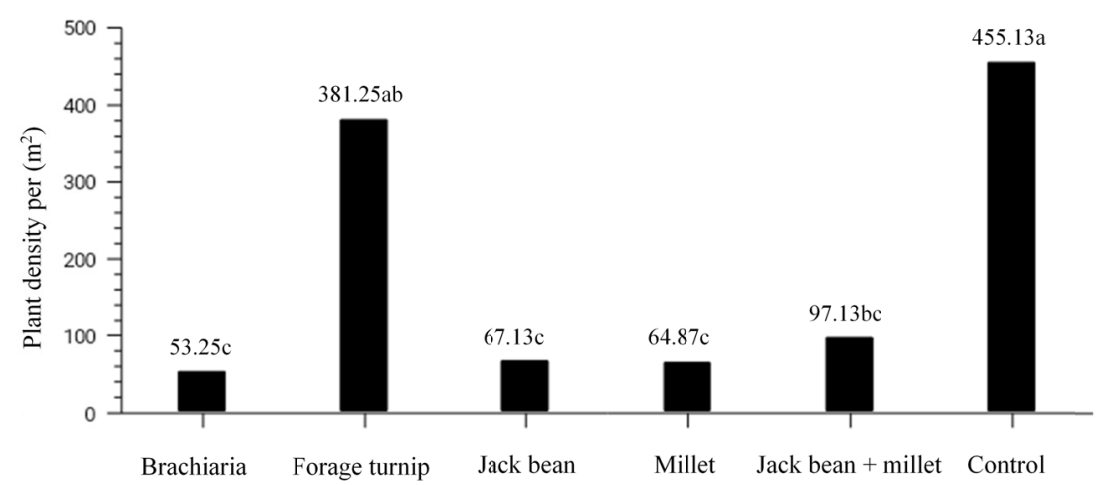

Figure 3. Effect of cover plant suppression on weed density (plants $\mathrm{m}^{-2}$ ) at 90 days after sowing of cover species. Rio Preto da Eva, AM, Brazil 
Treatments with the cover plants brachiaria, jack bean, millet, and jack bean + millet caused a suppressive effect on weeds due to a higher phytomass production and higher growth rate in relation to the other treatments. It can also be attributed to physical and allelopathic phenomena. Duarte et al. (2014) reported that among the characteristics that a vegetation cover must present to be effective in the management of weeds is the high phytomass production, a deep root system, and a rapid establishment in the area. With the cover plants on the ground, there is a decrease in the germination of positive photoblastic seeds, affecting those that require a large thermal amplitude to activate the germination process (Gomes, Bevilaqua, Silva, \& Monquero, 2014). The allelopathic potential of a cover plant depends on the plants growing at the same site, the amount of plant residues, and the types of substances released in the soil (Cruz-Silva, Matiazzo, Pacheco, \& Nóbrega, 2015).

Forage turnip was not efficient in suppressing weeds when compared to other cover plants. This result may be related to a low dry matter production and growth rate of this species. Moraes, Agostinetto, Vignolo, Santos, and Panozzo (2009) compared forage turnip with other cover plants and found that, in general, it allowed a higher weed development. Another factor that may have influenced a higher number of weeds was a higher light incidence on the soil, stimulating the germination of positive photoblastic seeds.

The control treatment presented high values of weed density. This result shows that the use of cover species, especially grasses and legumes, considerably reduces the density of these weeds (Figure 3).

The treatments brachiaria, jack bean, millet, and jack bean + millet showed a suppressive effect on weeds with an efficiency of $92,90,90$, and $85 \%$, respectively (Figure 4). Among the cover plants, forage turnip allowed a higher weed development, presenting a lower efficiency $(40 \%)$ when compared to other treatments.

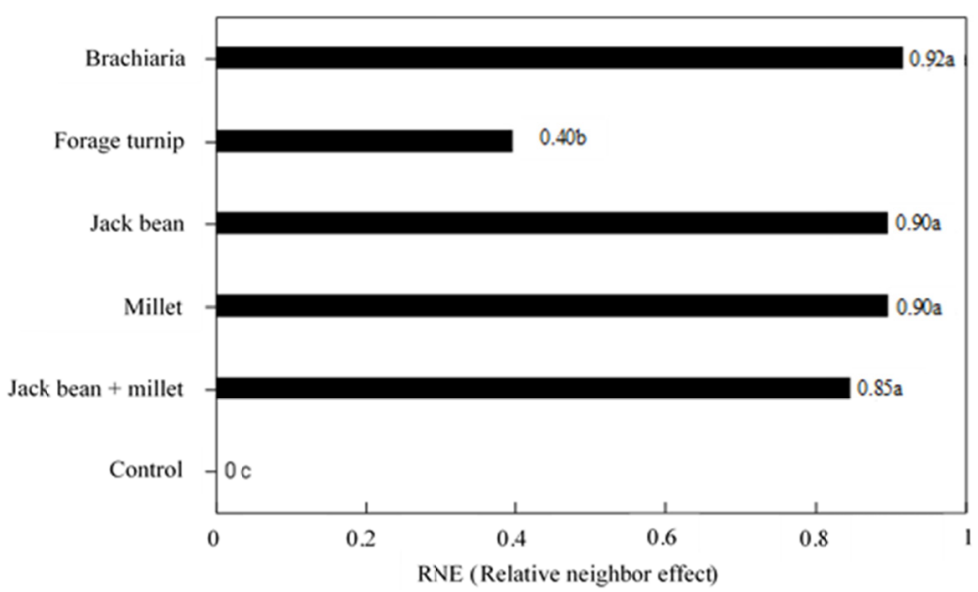

Figure 4. Relative neighbor effect (RNE) of the treatments (cover crops) for the three main functional types of weeds from the seed bank of the resident plants. Means followed by the same letter in the bars do not differ from each other by Tukey's test at $5 \%$ probability $(p \leq 0.05)$

The kinetics of the decomposition process of crop residues of cover plants was similar, with a decreasing rate following an exponential over time (Figure 5). 


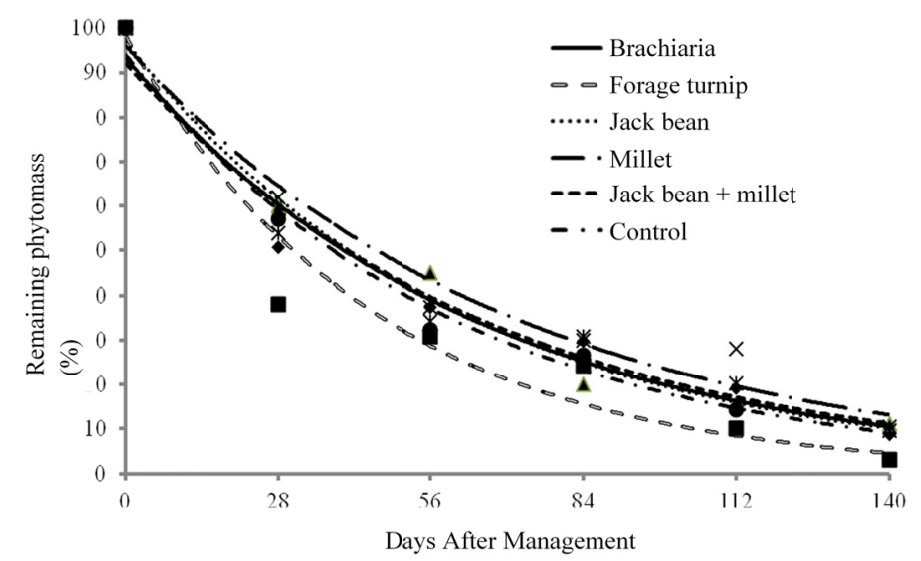

Figure 5. Remaining dry phytomass of residues of the treatments in the orange interrow. Rio Preto da Eva, AM, Brazil, 2012

Among the cover plants, the decomposition rate of crop residues presented a similar pattern, with a progressive decrease in dry matter, which was more pronounced for forage turnip (Figure 5), a pattern also observed by Balbinot Jr, Moraes, and Backes (2007). Millet showed the highest amount of remaining dry matter among the studied cover plants in all assessed periods, while the forage turnip presented an inverse pattern, with the lowest values of remaining dry matter in all assessed periods.

In a study carried out in Rondonópolis, MT, Brazil, Venegas and Scudeler (2012) assessed the effect of different cover plants on corn production and observed in millet the best vegetation cover when compared to forage turnip, crotalaria, brachiaria, and bare soil, also showing better results for dry matter, which is in accordance with the results of our experiment.

The decomposition rate of crop residues was high, with dry matter losses for brachiaria, forage turnip, jack bean, millet, jack bean + millet, and control in the order of $62.70,69.13,62.66,55.00,65.88$, and $67.58 \%$ at 56 days, respectively, after the distribution of the decomposition bags on the soil (Figure 5).

Acosta, Amado, Silva, Santi, and Weber (2014) assessed the decomposition and release of nitrogen (N) from residues of black oat, forage turnip, and vetch through decomposition bags. The highest decomposition rate of crop residues and the highest $\mathrm{N}$ release followed the order vetch $>$ forage turnip $>$ black oat. The $\mathrm{C} / \mathrm{N}$ ratio of crop residues influenced the magnitude of the phytomass of cover plants.

At 140 days, millet, jack bean, jack bean + millet, and the brachiaria showed between 88 and $91 \%$ of initial dry matter decomposition, while forage turnip and control had 97 and $99 \%$, respectively. These high values obtained for the decomposition rate may be justified by a higher soil moisture observed in this period mainly due to the precipitation indexes occurring in the period from May to September $(453 \mathrm{~mm})$, which are common in this region.

Other studies have proved the influence of precipitation on the decomposition rate of crop residues, with an increased decomposition as precipitation increases and a decreased decomposition as the minimum values of precipitation decreases in the dry period of the year (Teixeira, Loss, Pereira, \& Pimentel, 2012; Pacheco, Pereira, Silva, \& Alvarenga, 2013).

Legumes add significant amounts of nitrogen through the biological fixation process (BNF) in symbiosis with bacteria and crop residues of this species, which release a higher amount of this nutrient when in decomposition to the successor crops due to its lower $\mathrm{C} / \mathrm{N}$ ratio when compared to grasses (Lima Filho, Ambrosano, Rossi, \& Carlos, 2014).

Among the cover plants, millet had a lower rate of degradation (Figure 5). This latter cover showed to be highly persistent during the experimental period. These results are associated with the $\mathrm{C} / \mathrm{N}$ ratio, a dominant factor in most of the decomposition processes of each vegetation cover, confirming that non-grass species remain a shorter time protecting the soil because they have a higher decomposition rate when compared to grasses (Ziech et al., 2015).

Some authors mention that plant residue with a high $\mathrm{C} / \mathrm{N}$ ratio $(>25)$ form a stable mulch, a situation that occurs in Poaceae species (Teixeira, Carvalho, Andrade, Silva, \& Pereira, 2009; Carvalho, W., Carvalho, G., Abbarde Neto, \& Teixeira, 2013). In residues with a low $\mathrm{C} / \mathrm{N}$ ratio $(<25)$, such as those of Fabaceae species, mineralization is faster, especially when used as monocultures. 
The values obtained for the decomposition constant $(\mathrm{k})$, half-life time $\left(\mathrm{T}^{1 / 2}\right)$, equations, and determination coefficients obtained from the regression analysis are shown in Table 3.

Table 3. Decomposition constant $(\mathrm{k})$, half-life time $\left(\mathrm{T}^{1 / 2}\right)$ in days, regression analysis, and determination coefficient of dry matter of cover plants in the orange orchard. Rio Preto da Eva, AM, Brazil, 2012

\begin{tabular}{lllll}
\hline \multirow{2}{*}{ Cover plant } & \multicolumn{4}{c}{ Decomposition of the remaining phytomass } \\
\cline { 2 - 5 } & ${\mathrm{k}\left(\mathrm{g} \mathrm{g}^{-1}\right)}^{\text {Brachiaria }}$ & $\mathrm{T}^{1 / 2}$ (day) & Equation & $\mathrm{r}^{2}$ \\
\hline Forage turnip & 0.01872 & 37 & $\mathrm{y}=100.95 \mathrm{e}^{-0.017 \mathrm{x}}$ & 0.95 \\
Jack bean & 0.02482 & 28 & $\mathrm{y}=106.4 \mathrm{e}^{-0.019 \mathrm{x}}$ & 0.74 \\
Millet & 0.01572 & 44 & $\mathrm{y}=72.004 \mathrm{e}^{-0.015 \mathrm{x}}$ & 0.91 \\
Jack bean + millet & 0.01597 & 44 & $\mathrm{y}=93.11 \mathrm{e}^{-0.013 \mathrm{x}}$ & 0.87 \\
Control & 0.01667 & 42 & $\mathrm{y}=77.759 \mathrm{e}^{-0.016 \mathrm{x}}$ & 0.91 \\
\hline
\end{tabular}

The cover plants jack bean and millet underwent 50\% decomposition of residues $\left(\mathrm{T}^{1 / 2}\right)$ at 44 days after the placement of bags in the field. Brachiaria presented a $\mathrm{T}^{1 / 2}$ at 37 days. In a study conducted in Uberaba, MG, Brazil, during the dry season, Torres, Silva, Cunha, Valle, and Pereira (2014) observed higher $\mathrm{T}^{1 / 2}$ for jack bean (52 days), millet (93 days), and brachiaria (70 days). These results show that climate directly affects the decomposition of cover crop residues on the soil.

Considering the spontaneous vegetation of the experimental area, the control treatment presented a much lower $\mathrm{T}^{1 / 2}$ of 39 days when calculated up to 112 days after the management, since in this period the treatment still had the remaining dry matter in the field.

Jack bean + millet presented an intermediate half-life of 42 days. For the soil cover maintenance function, organic residues derived from grasses may present lower decomposition rates, and they are considered to be more interesting in the management plan. On the other hand, materials from legumes can recycle nutrients more quickly (Teixeira et al., 2009). In this research, the grass/legume combination can be considered an interesting option for the production system since it demonstrated a pattern of intermediate decomposition to single crops, while at the same time promoting the functions of soil protection and nutrient recycling in the medium term.

The treatment forage turnip presented a half-life of 28 days. The straw of forage turnip has a low persistence in relation to grasses. The degradation rate is directly related to humidity and temperature conditions that affect the activity of decomposing organisms, i.e., the higher the temperature and humidity are, the higher the degraded phytomass fraction (Hentz, Carvalho, Luz, \& Barcellos, 2014). In addition, other factors such as the development stage of the species in which the management and the chemical composition of the cultivated plant material were carried out justify the observed decomposition rate (Vilanova et al., 2014; Hentz et al., 2014).

According to Cardoso, Tsai, and Neves (1992), most plant residues are composed of more or less complex polymers, which initially undergo enzymatic hydrolysis with an essential performance of microbial exoenzymes. According to the ease of decomposition, some organic substances have a very short life in the soil, while others remain almost unchanged for long periods, such as high molecular weight phenolic compounds, which contain nitrogen and carbohydrates in their structure. Thus, succulent materials of young plants, such as cover plants, can undergo decomposition in a few weeks, as verified with some studied species.

Several authors, such as Teixeira et al. (2012) and Torres et al. (2014), state that climate conditions act directly on the soil microbial biomass, promoting the decomposition of plant residues and altering their decomposition rate, thus decreasing $\mathrm{T}^{1 / 2}$.

\section{Conclusion}

Brachiaria and jack bean presented the highest growth rates.

Cover plants suppressed weed growth in relation to the producer management, except for the forage turnip.

The highest decomposition rates occurred in the first 28 days, mainly for the forage turnip, which presented large losses in the initial phase and, after this period, a stabilization was observed in the decomposition rate of the remaining phytomass.

Brachiaria, jack beans, millet and their mixture presented longer half-life times, showing to be good alternatives for soil cover. 


\section{References}

Acosta, J. A. A., Amado, T. J. C., Silva, L. S., Santi, A., \& Weber, M. A. (2014). Decomposição da fitomassa de plantas de cobertura e liberação de nitrogênio em função da quantidade de resíduos aportada ao solo sob sistema plantio direto. Ciência Rural, 44(5), 801-809. https://doi.org/10.1590/S0103-84782014005000002

Alvares, C. A., Stape, J. L., Sentelhas, P. C., Gonçalves, J. L. M., \& Sparovek, G. (2013). Köppen's climate classification map for Brazil. Meteorologische Zeitschrift, 22(6), 711-728. https://doi.org/10.1127/ 0941-2948/2013/0507

Balbinot Jr., A. A., Moraes, A., \& Backes, R. L. (2007). Efeito de coberturas de inverno e sua época de manejo sobre a infestação de plantas daninhas na cultura de milho. Planta Daninha, 25(3), 473-480. https://doi.org/ $10.1590 / \mathrm{S} 0100-83582007000300006$

Borges, W. L. B., Freitas, R. S., Mateus, G. P., Sá, M. E., \& Alves, M. C. (2014). Supressão de plantas daninhas utilizando plantas de cobertura do solo. Planta Daninha, 32(4), 755-763. https://doi.org/10.1590/ S0100-83582014000400010

Cairo, P. A. R., Oliveira, L. E. M., \& Mesquita, L. C. (2008). Análise de crescimento de plantas (p. 72). Vitória da Conquista: Edições UESB.

Cardoso, E. J. B. N., Tsai, S. M., \& Neves, M. C. P. (1992). Microbiologia do solo (pp. 341-360). Campinas: Sociedade Brasileira de Ciência do Solo.

Carvalho, D. F., Montebeller, C. A., Franco, E. M., Valcarcel, R., \& Bertol, I. (2005). Padrões de precipitação e índices de erosividade para as chuvas de Seropédica e Nova Friburgo, RJ. Revista Brasileira de Engenharia Agricola e Ambiental, 9(1), 7-14. https://doi.org/10.1590/S1415-43662005000100002

Carvalho, J. E. B., Paes, J. M. V., \& Menegucci, J. L. P. (2001). Manejo de plantas daninhas em citros. Informe Agropecuário, 22(209), 1661-1670.

Carvalho, W. P., Carvalho, G. J., Abbarde Neto, D. O., \& Teixeira, L. G. V. (2013). Desempenho agronômico de plantas de cobertura usadas na proteção do solo no período de pousio. Pesquisa Agropecuária Brasileira, 48, 157-166. https://doi.org/10.1590/S0100-204X2013000200005

Castro, O. M., \& Lombardi Neto, F. (1992). Manejo e conservação do solo em citros. Laranja, 13(1), 275-305.

Coelho, Y. S., \& Nascimento, H. G. (2004). Citricultura no Amazonas: Problemas, Potencial Produtivo e Qualidade dos Frutos (p. 2). EMBRAPA. Embrapa Mandioca e Fruticultura, Cruz das Almas-BA.

Cruz-Silva, C. T. A., Matiazzo, E. B., Pacheco, F. P., \& Nóbrega, L. H. P. (2015). Allelopathy of crotalaria juncea L. aqueous extracts on germination and initial development of maize. Idesia, 33(1), 27-32. https://doi.org/ $10.4067 / \mathrm{S} 0718-34292015000100003$

Dorn, B. J. W., \& Van Der Heijden, M. G. A. (2015). Weed suppression by cover crops: Comparative on-farm experiments under integrated and organic conservation tillage. Weed Research, 55, 586-597. https://doi.org/ $10.1111 /$ wre. 12175

Duarte, I. B., Gallo, A. S., Gomes, M. S., Guimarães, N. F., Rocha, D. P., \& Silva, R. F. (2014). Plantas de cobertura e seus efeitos na biomassa microbiana do solo. Acta Iguazu, 3(2), 150-165.

EMBRAPA (Empresa Brasileira De Pesquisa Agropecuária). (2013). Sistema brasileiro de classificação de solos (3rd ed., p. 353). Brasília, Brazil.

Eshel, G., Egozi, R., Goldwasser, Y., Kashti, Y., Fine, P., Hayut, E., ... Disegni, D. M. (2015). Benefits of growing potatoes under cover crops in a Mediterranean climate. Agriculture, Ecosystems and Environment, 211, 1-9.

Faversani, J. C., Cassol, L. C., Piva, J. T., Minato, E. A., \& Rocha, K. F. (2014). Taxa de cobertura do solo com plantas submetidas a diferentes sistemas de preparo. Synergismus Scyentifica UTFPR, 09(1).

Gelmini, G. A., Trani, P. E., Sales, J. L., \& Victoria Filho, R. (1994). Manejo integrado de plantas daninhas (p. 25). Campinas: Instituto Agronômico.

Gfeller, A., Herrera, J. M., Tschuy, F., \& Mirth, J. (2018). Explanations for Amaranthus retroflexus growth suppression by cover crops. Crop Protection, 104, 11-20. https://doi.org/10.1016/j.cropro.2017.10.006

Gomes, D. S., Bevilaqua, N. C., Silva, F. B., \& Monquero, P. A. (2014). Supressão de plantas espontâneas pelo uso de cobertura vegetal de crotalária e sorgo. Revista Brasileira de Agroecologia, 9(2), 206-213.

Gravena, S. (1998). Guia de MEP-Citrus edição 98/99. Jaboticabal: GRAVENA. Manejo ecológico e controle 
biológico de pragas agrícolas Ltda.

Halde, C., Gulden, R. H., \& Entz, M. H. (2014). Selecting cover crop mulches for organic rotational no-till systems in Manitoba, Canada. Agronomy Journal, 106(4), 1193-1204. https://doi.org/10.2134/agronj13.0402

Hentz, P., Carvalho, N. L., Luz, L. V., \& Barcellos, A. L. (2014). Ciclagem de nitrogênio em sistemas de integração lavoura-pecuária. Ciência e Natura, 36, 663-676. https://doi.org/10.5902/2179460X12629

IBGE (Instituto Brasileiro De Geografia E Estatística). (2017). Levantamento Sistemático da produção Agrícola: Pesquisa mensal de previsão e acompanhamento das safras agrícolas no ano. Rio de Janeiro, 30(12), 1-82.

Lima Filho, O. F., Ambrosano, E. J., Rossi, F., \& Carlos, J. A. D. (2014). Adubação verde e plantas de cobertura no Brasil: fundamentos e prática (1st ed., p. 507). Brasília-DF: Embrapa.

Lineares, J. S. J., Boote, K., Chase, C. A., Ferguson, J. J., \& Mcsorley, R. (2008). Use of the cover crop weed index to evaluate weed suppression by cover crops in organic citrus orchards. Hortscience, 43(1). https://doi.org/10.21273/HORTSCI.43.1.27

Montanari, R., Carvalho, M. P., Teixeira Filho, M. C. M., \& Dalchiavon, F. C. (2013). Produção de matéria seca da braquiária de acordo com os atributos químicos de um Latossolo em Selvíria, Mato Grosso do Sul, Brasil. Revista Ceres, 60(4), 519-527. https://doi.org/10.1590/S0034-737X2013000400011

Moraes, P. V. D., Agostinetto, D., Vignolo, G. K., Santos, L. S., \& Panozzo, L. E. (2009). Manejo de plantas de cobertura no controle de plantas daninhas na cultura do milho. Planta Daninha, 27(2), $289-296$. https://doi.org/10.1590/S0100-83582009000200011

Pacheco, F. V., Pereira, C. R., Silva, R. L., \& Alvarenga, I. C. A. (2013). Crescimento inicial de Dalbergia nigra (Vell.) Allemão ex. Benth. (Fabaceae) e Chorisia speciosa A.St.-Hil (Malvaceae) sob diferentes níveis de sombreamento. Revista Árvore, 37(5), 945-953. https://doi.org/10.1590/S0100-67622013000500017

Paul, E. J., \& Clark, F. E. (1996). Soil as a habitat for organisms and their reactions. In E. J. Paul, \& F. E. Clark (Eds.), Soil Microbiology and Biochemistry (2nd ed., pp. 12-32). Academic Press, San Diago.

Reis, L. S., Azevedo, C. A. V., Albuquerque, A. W., \& Junior, J. F. S. (2013). Índice de área foliar e produtividade do tomate sob condições de ambiente protegido. Revista Brasileira de Engenharia Agrícola e Ambiental, 17(4), 386-391. https://doi.org/10.1590/S1415-43662013000400005

Silva, F. (2012), Assistat versão 7.6 beta. Assistência Estatística.

Smith, R. G., Atwood, L. W., Pollnac, F. W., \& Warren, N. D. (2015). Cover-crop species as distinct biotic filters in weed community assembly. Weed Science, 63, 282-295. https://doi.org/10.1614/WS-D-14-00071.1

Soares, A. M., Negreiros, M. Z., Lopes, W. A. R., Dombroski, J. L. D., \& Lucena, R. R. M. (2013). Crescimento do tomateiro cultivado em solo coberto com polipropileno preto. Revista Ciência Agronômica, 44(4), $790-797$. https://doi.org/10.1590/S1806-66902013000400016

Sturm, D. J., Peteinatos, G., \& Gerhards, R. (2018). Contribution of allelopathic effects to the overall weed suppression by different cover crops. Weed Research, 58, 331-337. https://doi.org/10.1111/wre.12316

Teixeira, C. M., Carvalho, G. J., Andrade, M. J. B., Silva, C. A., \& Pereira, J. M. (2009). Decomposição e liberação de nutrientes das palhadas de milheto e milheto + crotalária no plantio direto do feijoeiro. Acta Scientiarum Agronomy, 31(4), 647-653. https://doi.org/10.4025/actasciagron.v31i4.1356

Teixeira, M. B., Loss, A., Pereira, M. G., \& Pimentel, C. (2012). Decomposição e ciclagem de nutrientes dos resíduos de quatro plantas de cobertura do solo. Idesia, 30(1), 55-64. https://doi.org/10.4067/ S0718-34292012000100007

Thomas, R. J., \& Asakawa, N. (1993). Decomposition of leaf litter from tropical forage grasses and legumes. Soil Biology and Biochemistry, 25(10), 1351-1361.

Torres, J. L. R., Silva, M. G. S., Cunha, M. A., Valle, D. X. P., \& Pereira, M. G. (2014). Produção de fitomassa e decomposição de resíduos culturais de plantas de coberturas no cultivo da soja em sucessão. Revista Caatinga, 27(3), 247-253.

Uchino, H., Iwama, K., Jitsuyama, Y., Ichiyama, K., Sugiura, E., Yudate, T., ... Gopal, J. (2012). Effect of interseeding cover crops and fertilization on weed suppression under an organic and rotational cropping system. Field Crops Research, 127, 9-16. https://doi.org/10.1016/j.fcr.2011.10.007

Venegas, F., \& Scudeler, F. (2012). Diferentes coberturas vegetais na produção de milho (Zea mays L.). Ensaios e Ciência: Ciências Biológicas, Agrárias e da Saúde, 16(2), 9-20. 
Vilanova, C. C., Comin, J. J., Kurtz, C., Müller Jr, V., Uriarte, J. F. U., Ventura, B. S., ... Brunetto, G. (2014). Interferência de plantas de cobertura sobre a incidência de plantas invasoras e a produção de cebola sob sistema de plantio direto. Scientia Agraria, 15(1), 9-14. https://doi.org/10.5380/rsa.v15i1.41092

Welch, R. Y., Behnke, G. D., Davis, A. S., Masiunas, J., \& Villamil, M. B. (2016). Using cover crops in headlands of organic grain farms: Effects on soil properties, weeds and crop yields. Agriculture, Ecosystems and Environment, 216, 322-332. https://doi.org/10.1016/j.agee.2015.10.014

Ziech, A. R. D., Conceição, P. C., Luchese, A. V., Balin, N. M., Candiotto, G., \& Garmus, T. G. (2015). Proteção do solo por plantas de cobertura de ciclo hibernal na região Sul do Brasil. Pesquisa Agropecuária Brasileira, 50(5), 374-382. https://doi.org/10.1590/S0100-204X2015000500004

\section{Copyrights}

Copyright for this article is retained by the author(s), with first publication rights granted to the journal.

This is an open-access article distributed under the terms and conditions of the Creative Commons Attribution license (http://creativecommons.org/licenses/by/4.0/). 